\title{
Investigating the effect of growth and financial strength variables on the financial leverage: Evidence from the Tehran Stock Exchange
}

\author{
Iman Dadashi $^{\mathbf{a}^{*} \text {, Elham Mansourinia }}{ }^{\mathrm{b}}$, Milad Emamgholipour ${ }^{\mathrm{b}}$, Seyedeh Maryam Babanejad \\ Bagheri $^{\mathrm{a}}$ and Ali Mohammadpour Arabi ${ }^{\mathrm{c}}$
}

\begin{abstract}
${ }^{a}$ Department of Accounting, Babol Branch, Islamic Azad University, Babol, Iran
${ }^{b}$ Young Researchers Club, Babol Branch, Islamic Azad University, Babol, Iran

${ }^{C}$ Master's Degree in Accounting

C H R O N I C L E

Article history:

Received December 1, 2012

Received in revised format

2 March 2013

Accepted 10 March 2013

Available online

March 122013

Keywords:

Financial leverage

Firm growth

Financial strength

A B S T R A C T

The primary objective of this study is to investigate the effect of growth and financial strength variables on the financial leverage for some listed companies in the Tehran Stock Exchange. For this purpose, a sample of 700 firm-years among listed companies in the Tehran Stock Exchange over the period 2006-2010 was examined. In the present study, the growth variables, including asset growth, profit growth and sales growth; and financial strength calculated by the Altman Z-bankruptcy model have been considered as independent variables. In addition, the ratios of long-term debt to total assets, long-term debt to fixed assets, total long-term debt and short-term receivable facilities to equity capital and total long-term debt and short-term receivable facilities to total assets are used as measures of financial leverage and dependent variables. The results indicate that there is a negative and significant relationship between assets growth and some indexes of financial leverage. There is also a positive and significant relationship between the variables of profit growth, sales growth and financial strength with financial leverage measures.
\end{abstract}

\section{Introduction}

Today, one of the discussed instances in economic issues in various communities is economic development and growth discussion. In order to achieve this purpose we need to use appropriate tools and mechanisms to lead funds towards growth and development of production and trade. Management should be able to select comparative growth targets and operate them based on suitable environment of business activities. An important step in the start of firm growth is change in management style. Surely, this change requires professional management tools. Some experts believe that the change point is associated with an early crisis of growth and appropriate and fair handling of crisis is correlated with imposition the growth and changes of company (Davila \& Foster, 2005). The

Corresponding author. Tel: +98-912-4400915 E-mail: i.dadashi@gmail.com (I. Dadashi)

(C) 2013 Growing Science Ltd. All rights reserved. doi: 10.5267/j.msl.2013.03.014 
firm growth announces the amount of power and ability of company in transmission of useful information for managers to make appropriate decisions. Business units with high sales and asset growth are typically known as a growing business unit.

In the growth stage of firm size, sales growth and profit growth are more than in early stage of creation and companies at this stage invest in significant amount of cash and resources. In this stage, all employees are required to have necessary training so that company could reach to established merits. The amount of companies' risk, likelihood of bankruptcy, is high in the early stages of growth (Piry et al., 2011). Poor management, inadequate capital structure, choice of improper accounting practices; poor liquidity conditions are factors, which are largely effective in the outbreak of financial crisis of firms. One of the most important risks, which threaten many business units regardless of their activity type, is inability to pay obligations. Inability to pay obligations means lack of sufficient liquidity to pay the firm's debts in maturity that is one of the most reasons for announcing bankruptcy. When total liabilities of company exceed the market value of its total assets, the company may go under bankruptcy protection. Therefore, business unit must use an amount of financial facilities to make sure even in unfavorable economic conditions could still repay the facilities.

In order to recognize the future growth opportunities, managers must make adjustments in operation of company; these adjustments could be a change in the amount of leverage. Leverage is a warning from the information of managers about the investment opportunities.

The companies' rating in terms of creditability largely is associated with their capital structure. In order to have a good growth and development in any business unit, many financial resources are needed. Therefore, determining the optimal capital structure is one of the most important issues facing managers and it is felt that the effect of how to finance in capital structure should get more attention.

Financial leverage, in order to provide some of the company's assets may impose fixed payments through securities to the company (Aydemir et al., 2007). Leverage is indicative of solutions for the business unit to use provided financial resources to perform company's obligations. Management can adopt appropriate and timely decisions also need adequate information on how to calculate and evaluate financial leverage.

Management with recognition the company's future growth opportunities may appropriately reduce financial leverage and blur its effect on growth (Noravesh \& Yazdani, 2010). Growing business units, with accumulating profits, cause to increase the stock prices. Also with sales growth over time, regardless of adopted decisions of management, current liabilities of the company also increase.

Any increase in the number of outstanding shares can also be a sign of growth and development or profitability plans in progress. Debt (bank loans) also can report favorable investment opportunities of company, but with created financial leverage, problems such as the probability of bankruptcy and non-payment of debts are created (Rahnamaye Roodposhti et al., 2009).

The purpose of this study is to evaluate and find out important variables on growth and financial strength of company influencing on financial leverage. In this study, similar studies are reviewed first, then hypotheses are formulated, research realm is specified, data are analyzed and hypotheses are tested using regression and finally research results will presented.

\section{Literature Review}

Chahine et al. (2007) evaluated the effect of investment in R \& D and firm size on firm growth for 831 companies from Canada, France, Germany and Italy over the period 1986-1998. The results of their study indicated that there was a negative and significant relationship between growth opportunities with financial leverage and firm size. 
Bebczuk and Galindo (2010) performed an investigation using financial data from 185 listed companies in the stock exchanges on six countries in Latin America, over the period 1993-2009. They reported that, financial leverage had positive and significant relationship with firm size, tangible fixed assets ratio and market value to book value ratio. In another study conducted by Kumar et al. (2012) they reported that there was a positive and significant relationship between capital structure and firm growth rate. Arabzadeh (2012) conducted a survey on 56 listed companies in Tehran Stock Exchange over the period 2001-2005 and reported that there was a positive and significant relationship between the growth rates of company and financial leverage. However, a significant and negative correlation was observed between the risk of operating profit and financial leverage.

Zhao and Wijewardana (2012) investigated financial leverage, firm growth and financial strength of 62 listed companies in the stock exchange in Sri Lanka over the period 2000-2009. In this study, the ratios of long-term debt to total assets, long-term debt to fixed assets, total long-term debt and shortterm receivable facilities to equity capital and total long-term debt and short-term receivable facilities to total assets were used as measures of financial leverage. The results indicated that there was a significant relationship between variables of profit and sales growth of company and financial strength with the ratios of total long-term debt and short-term receivable facilities to equity capital and total long-term debt and short-term receivable facilities to total assets.

Monica and Abir (2010) tested the relationship between financial leverage and investment opportunities in 963 listed companies in the Bombay Stock Exchange over the period 2004-2008. The research results showed that there was a significant and negative relationship between firm growth and capital structure. Kjell and Randi (2010) studied the relationship between bankruptcy risk and growth of Norwegian firms over the period 1988-2007. They found that companies with high bankruptcy risk would have high expected future growth. Akhtar et al. (2012) reported that there was a significant correlation between financial leverage and sales growth.

Anderson (2002) in his study investigated the effect of capital structure on growth and liquidity of Belgian and Canadian firms over the period 1989-2001. The results indicated that there was positive and significant relationship between financial leverage and held cash assets. Also high ratio of debt led to the identification high liquidity and low growth. Hassani and Mahdavi Sabet (2013) in their study reached to this conclusion that there was a negative and significant relationship between financial leverage and future cash flows. However, there is a significant positive relationship between the firm growth and future cash flows.

Sinai et al. (2011) studied the effect of growth opportunities on the relationship between capital structure, dividend and ownership structure with firm value in 110 listed companies in Tehran Stock Exchange over the period 2004-2009. The results showed that there was a significant relationship between financial leverage and dividend with firm value and in the mode of existence growth opportunities, this relationship was negative and significant, but without growth opportunities, the relationship was a positive and significant. Houshmand Neghabi and Morshedian Rafiee (2013) in their study reached to this conclusion that there was a significant positive relationship between the growth rates of company and capital structure. However, a significant relationship was not observed between operational risk and capital structure.

Noravesh and Yazdani (2010) in their study investigated the effect of financial leverage on investment of 98 listed companies in the Tehran Stock Exchange during the time span of 2001-2006. The results indicated that there was a negative and significant relationship between financial leverage and investment and also the relationship between leverage and investment for companies with less growth opportunity was stronger than companies with more growth opportunity. Alaghi (2011) studied the relationship between financial leverage and systemic risk on the 58 listed companies in Tehran Stock Exchange over the period 2006-2009. The results showed that there was a positive and significant relationship between financial leverage and systematic risk. 


\section{Research Hypotheses}

To investigate the effect of variables of firm growth and financial strength on the financial leverage, the following hypotheses are formulated to test:

First hypothesis: There is a significant relationship between assets growth and financial leverage. Second hypothesis: There is a significant relationship between net profit growth and financial leverage.

Third hypothesis: There is a significant relationship between net sales growth and financial leverage. Fourth hypothesis: There is a significant relationship between financial strength and financial

\section{Research Design} leverage.

\subsection{Statistical Population and Sample}

Statistical society of the present study includes all companies listed in Tehran Stock Exchange. For selecting the statistical sample, the following conditions are considered:

1. They are listed in stock before the year 2006.

2. In order to compare the data, the end of fiscal year of companies lead up to December 31.

3. In order to information homogeneity, they are not among financial companies.

4. Their financial period has not changed during the studied fiscal year.

Considering the above conditions, 140 companies during the period 2006-2010 were selected. Required data has been collected from the site of the Tehran Stock Exchange ${ }^{1}$ and CDs of financial information of companies listed in Tehran Stock Exchange.

\subsection{Methods of Data Analysis and Hypothesis Testing}

The present study is description in terms of nature and correlation in terms of method and it is application in terms of target and its main target is determination of existence, the amount and type of relationship between variables. Test hypotheses are done using collected synthetic data. To test the hypotheses, a multivariate regression model is used. Fisher F statistic is used to determine the overall adequacy of the regression model and the adjusted $\mathrm{R}^{2}$ is used to explain changes of dependent variable by independent variables. To evaluate the significance of the coefficients of independent variables has been used t-student statistic and to investigate lack of autocorrelation problem between sentences of model error has been used Durbin- Watson test (DW).

\subsection{Operational Research Models and Variables}

In this study, in order to investigate the effect of firm growth and financial strength on the financial leverage of listed companies in the Tehran Stock Exchange, we use the ratios of long-term debt to total assets, long-term debt to fixed assets, total long-term debt and short-term receivable facilities to equity capital as independent variables. In addition, we also use the ratios of total long-term debt and short-term receivable facilities to total assets as dependent variables. Finally, asset growth, profit growth, sales growth and financial strength are used as independent variables. How to calculate each of these variables is presented in Table 1. To test the research hypotheses were used the following regression models.

$$
L E V_{i t}=\beta_{0}+\beta_{1} A G_{i t}+\beta_{2} P G_{i t}+\beta_{3} S G_{i t}+\beta_{4} F S_{i t}+\varepsilon_{i t},
$$

where

${ }^{1}$ www.irbourse.com 
$\mathrm{LEV}_{\mathrm{it}}$ = financial leverage of firm $\mathrm{i}$ in year t which is measured using four indicators, long-term debt to total assets ratio (LD/TA), Long-term debt to fixed assets ratio (LD/FA), total long-term debt and short-term receivable facilities to equity capital ratio (TD/EC) and total long-term debt and short-term receivable facilities to total assets ratio (TD/TA),

$\mathrm{AG}_{\mathrm{it}}=$ Assets growth of firm $i$ in year $t$,

$\mathrm{PG}_{\mathrm{it}}=$ Profit growth of firm $i$ in year $t$,

$\mathrm{SG}_{\text {it }}=$ Sales growth of firm $i$ in year $t$,

$\mathrm{FS}_{\mathrm{it}}=$ Financial strength of firm $i$ in year $t$,

$\varepsilon_{i t}=$ Error component of model of firm $i$ in year $t$,

$\beta_{0}=$ Constant coefficient (the intercept) and $\beta_{1}$ to $\beta_{4}=$ coefficients of independent variables.

Table 1

Dependent and Independent Variables and how they are calculated

\begin{tabular}{|c|c|c|}
\hline Variables & Symbol & Definition \\
\hline \multicolumn{3}{|c|}{ Dependent Variables } \\
\hline Long-term debt to total assets ratio & $\mathrm{LD} / \mathrm{TA}$ & Long-term debt / Total assets \\
\hline Long-term debt to fixed assets ratio & LD/FA & Long-term debt / Fixed assets \\
\hline $\begin{array}{l}\text { Total long-term debt and short-term } \\
\text { receivable facilities to equity capital ratio }\end{array}$ & TD/EC & $\begin{array}{l}\text { Short-term receivable facilities + Long-term debt / Equity } \\
\text { capital }\end{array}$ \\
\hline $\begin{array}{l}\text { Total long-term debt and short-term } \\
\text { receivable facilities to total assets ratio }\end{array}$ & $\begin{array}{l}\text { TD/TA } \\
\text { Indepe }\end{array}$ & $\begin{array}{l}\text { Short-term receivable facilities+ Long-term debt / Total assets } \\
\text { ndent Variables }\end{array}$ \\
\hline Asset growth & AG & $\begin{array}{l}\text { total assets of last year - total assets of current year / total assets } \\
\text { of last year }\end{array}$ \\
\hline Profit growth & PG & $\begin{array}{l}\text { net profit of last year - net profit of current year / net profit of } \\
\text { last year }\end{array}$ \\
\hline Sales growth & SG & $\begin{array}{l}\text { net sales of last year - net sales of current year / net sales of last } \\
\text { year }\end{array}$ \\
\hline Financial strength & FS & $\begin{array}{l}\mathrm{Z}=0.012 \mathrm{X}_{1}+0.014 \mathrm{X}_{2}+0.033 \mathrm{X}_{3}+0.006 \mathrm{X}_{4}+0.999 \mathrm{X}_{5} \\
\mathrm{X}_{1}=\text { Working capital } / \text { Total assets } \\
\text { Working capital }=\text { Current Assets }- \text { Current Liabilities } \\
\mathrm{X}_{2}=\text { Retained earnings /Total assets } \\
\mathrm{X}_{3}=\text { Operating profit /Total assets } \\
\mathrm{X}_{4}=\text { Market value of equity /Total debts } \\
\mathrm{X}_{5}=\text { Net sales/ Total assets }\end{array}$ \\
\hline
\end{tabular}

\section{Research Findings}

The results of the test research hypotheses are presented in Table 2. The first hypothesis investigates the relationship between asset growth and financial leverage. As can be seen from the results of the table, statistically, there is a significant and negative relationship between asset growth (AG) and variables of long-term debt to total assets ratio (LD/TA) and total long-term debt and short-term receivable facilities to total assets ratio (TD/TA) at error level less than $1 \%$. However, significant relationships between asset growth (AG) and variables of long-term debt to fixed assets (LD/FA) and total long-term debt and short-term receivable facilities to equity capital ratio (TD/EC) were not observed.

The second hypothesis of research suggests there is a significant relationship between profit growth and financial leverage. The results indicate that there were no significant relationships between the profit growth (PG) and long-term debt to fixed assets ratio (LD/FA). However, statistically there was a significant and positive relationship between profit growth (PG) and variables of long-term debt to total assets ratio (LD/TA) and total long-term debt and short-term receivable facilities to total assets ratio (TD/TA) at error level less than $1 \%$ and $10 \%$, respectively. In addition, a significant and 
negative relationship between profit growth (PG) and total long-term debt and short-term receivable facilities to equity capital ratio (TD/EC) were observed.

The third hypothesis of research states that there is a significant relationship between sales growth and financial leverage. The results show that there was a significant and positive relationship between sales growth (SG) and variables of long-term debt to total assets ratio (LD/TA), long-term debt to fixed assets ratio (LD/FA), and total long-term debt and short-term receivable facilities to equity capital ratio (TD/EC) at error level of $1 \%, 5 \%$ and $1 \%$ respectively. However, significant relationship between sales growth (SG) and total long-term debt and short-term receivable facilities to total assets ratio (TD/TA) were not observed.

Finally, the results from the fourth hypothesis testing of research have shown that statistically there was a significant and positive relationship between financial strength (FS) and three indicators of financial leverage including long-term debt to total assets ratio (LD/TA), total long-term debt and short-term receivable facilities to equity capital ratio (TD/EC) and total long-term debt and short-term receivable facilities to total assets ratio (TD/TA) at the error level less than $1 \%$. However, there was no significant relationship between financial strength (FS) and long-term debt to fixed assets ratio (LD/FA).

Table 2

Test results of research hypotheses

\begin{tabular}{|c|c|c|c|}
\hline \multicolumn{4}{|c|}{ Dependent Variable: long-term debt to total assets ratio (LD/TA) } \\
\hline Variables & Coefficient & t-Statistic & Sig. \\
\hline Constant & -0.005 & -0.286 & 0.775 \\
\hline Assets growth & -0.206 & -4.770 & 0.000 \\
\hline Profit growth & 0.006 & 3.371 & 0.001 \\
\hline Sales growth & 0.075 & 3.255 & 0.001 \\
\hline Financial strength & 0.145 & 9.740 & 0.000 \\
\hline \multicolumn{2}{|c|}{ Adjusted $\mathrm{R}^{2}: 0.196$} & \multicolumn{2}{|c|}{ F-statistic: 42.935} \\
\hline \multicolumn{2}{|c|}{ Prob(F-statistic): 0.000} & \multicolumn{2}{|c|}{ Durbin Watson: 2.127} \\
\hline \multicolumn{4}{|c|}{ Dependent Variable: long-term debt to fixed assets ratio (LD/FA) } \\
\hline Variables & Coefficient & t-Statistic & Sig. \\
\hline Constant & 0.502 & 12.026 & 0.000 \\
\hline Assets growth & -0.157 & -1.570 & 0.117 \\
\hline Profit growth & 0.008 & 1.197 & 0.232 \\
\hline Sales growth & 0.109 & 2.045 & 0.041 \\
\hline Financial strength & -0.038 & -1.098 & 0.273 \\
\hline Adjusted $\mathrm{R}^{2}: 0.005$ & & \multicolumn{2}{|c|}{ F-statistic: 1.891} \\
\hline Prob(F-statistic): 0.110 & & \multicolumn{2}{|c|}{ Durbin Watson: 1.758} \\
\hline \multicolumn{4}{|c|}{ Dependent Variable: total long-term debt and short-term receivable facilities to equity capital ratio(TD/EC) } \\
\hline Variables & Coefficient & t-Statistic & Sig. \\
\hline Constant & 2.134 & 8.532 & 0.000 \\
\hline Assets growth & -0.173 & -0.288 & 0.773 \\
\hline Profit growth & -0.200 & -5.216 & 0.000 \\
\hline Sales growth & 0.860 & 2.704 & 0.007 \\
\hline Financial strength & 0.657 & 3.171 & 0.002 \\
\hline \multicolumn{2}{|c|}{ Adjusted R²: 0.058} & \multicolumn{2}{|c|}{ F-statistic: 11.682} \\
\hline \multicolumn{2}{|c|}{ Prob(F-statistic): 0.000} & \multicolumn{2}{|c|}{ Durbin Watson: 1.816} \\
\hline \multicolumn{4}{|c|}{ Dependent Variable: total long-term debt and short-term receivable facilities to total assets ratio(TD/TA) } \\
\hline Variables & Coefficient & t-Statistic & Sig. \\
\hline Constant & 0.183 & 6.940 & 0.000 \\
\hline Assets growth & -0.336 & -5.315 & 0.000 \\
\hline Profit growth & 0.007 & 1.738 & 0.083 \\
\hline Sales growth & 0.021 & 0.623 & 0.533 \\
\hline Financial strength & 0.241 & 11.002 & 0.000 \\
\hline 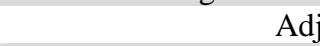 & & & \\
\hline Prob( & & & \\
\hline
\end{tabular}


The value of $F$ statistics in Table 2 shows that all regression models, except model whose dependent variable is long-term debt to fixed assets ratio (LD/FA), in general are significant at the 99\% confidence level. According to adjusted coefficient, we can claim that about $20 \%$ of changes in longterm debt to total assets ratio (LD/TA) and total long-term debt and short-term receivable facilities to total assets ratio (TD/TA), 0.5\% changes in the long-term debt to fixed assets ratio (LD/FA), and 6\% changes in total long-term debt and short-term receivable facilities to equity capital ratio (TD/EC) (as indicators of financial leverage) can be explained by the research independent variables.

In addition, the value of Durbin-Watson statistic of regression models is between 1.5 and 2.5. Therefore, we can conclude that violation component of models in studied periods are independent. In other words, the amounts of violation component of model are random and the assumption of autocorrelation existence between variables is rejected.

\section{Conclusions}

Since the companies' rating in terms of creditability largely is related to their capital structure. In order to growth and development of business unit, many financial resources are needed. Therefore, determination of optimal capital structure is one of the most important issues facing managers and it is felt that the effect of how to finance in capital structure should get more attention. Therefore, this study investigates the effect of growth and financial strength variables of company on financial leverage of listed companies in Tehran Stock Exchange. Statistical universe of the present study is all companies that have been listed in Tehran Stock Exchange from beginning of year 2006. Among the member companies of community, 140 companies randomly are considered as statistical sample of study among companies, which were eligible for the study. Summary of the results of research hypotheses testing are presented in Table 3.

\section{Table 3}

Summary of the test results of research main hypotheses

\begin{tabular}{|c|c|c|c|c|c|c|c|c|c|}
\hline \multirow{2}{*}{$\begin{array}{l}\text { The main } \\
\text { hypotheses }\end{array}$} & \multirow{2}{*}{$\begin{array}{c}\text { Dependent } \\
\text { variables } \\
\text { Independent } \\
\text { variables }\end{array}$} & \multicolumn{2}{|c|}{$\mathrm{LD} / \mathrm{TA}$} & \multicolumn{2}{|c|}{ LD/FA } & \multicolumn{2}{|c|}{ TD/EC } & \multicolumn{2}{|c|}{ TD/TA } \\
\hline & & Result & Relationship & Result & Relationship & Result & Relationship & Result & Relationship \\
\hline $\mathrm{H}_{1}$ & Asset growth & Confirmed & Negative & Rejected & - & Rejected & - & Confirmed & Negative \\
\hline $\mathrm{H}_{2}$ & Profit growth & Confirmed & Positive & Rejected & - & Confirmed & Negative & Confirmed & Positive \\
\hline $\mathrm{H}_{3}$ & Sales growth & Confirmed & Positive & Confirmed & Positive & Confirmed & Positive & Rejected & - \\
\hline $\mathrm{H}_{4}$ & Financial strength & Confirmed & Positive & Rejected & - & Confirmed & Positive & Confirmed & Positive \\
\hline
\end{tabular}

In the present study, the growth variables, including asset growth, profit growth, sales growth and financial strength, which are calculated by Altman Z-bankruptcy model, have been considered as independent variables. Also, long-term debt to total assets ratio (LD/TA), long-term debt to fixed assets (LD/FA), total long-term debt and short-term receivable facilities to equity capital ratio (TD/EC) and total long-term debt and short-term receivable facilities to total assets ratio (TD/TA) were used as indicators of financial leverage and dependent variables.

In order to investigate the relationship between independent variables and dependent variables of the study, four hypotheses were formulated and were tested using four regression models. Test results of the first hypothesis show that there was a significant and negative relationship only between asset growth and two indicators of financial leverage (LD/TA and TD/TA). This indicates that, if the assets of the company increase in the studied years, these two indicators of financial leverage will be reduced. Test results of the second hypothesis show that there is a significant and positive relationship between net profit growth of company and two indicators of LD/TA and TD/TA and indicates that companies with financing through debt in the studied years can have growth in net profit. The results of the third hypothesis have approved the positive and significant relationship between net sales growth and three indicators of financial leverage that is LD/TA, LD/FA and TD/EC. This relationship shows companies, which have high net sales growth, have high financial leverage. 
Finally, the test results of fourth hypothesis have shown that there is a significant and positive relationship between financial strength of companies and three indicators of LD/TA, TD/EC and TD/TA (financial leverage) and represents, an increase in the amount of Z-Altman bankruptcy model is associated with an increase in financial leverage of the companies.

\section{References}

Akhtar, S., Javed, B., Maryam, A., \& Sadia, H. (2012). Relationship between Financial Leverage and Financial Performance: Evidence from Fuel \& Energy Sector of Pakistan. European Journal of Business and Management, 4(11), 7-17.

Alaghi, K. (2011). Financial leverage and systematic risk. African Journal of Business Management, 5(15), 6648-6650.

Anderson, R.W. (2002). Capital structure, firm liquidity and growth. Working Paper.

Arabzadeh, M. (2012). A study on effects of cost-of-equity models on cost-of-capital and capital structure. Management Science Letters, 2(6), 1855-1864.

Aydemir, A. C., Gallmeyer, M., \& Hollifield, B. (2007). Financial Leverage and the Leverage EffectA Market and Firm Analysis. Tepper School of Business, 142.

Bebczuk, R., \& Galindo, A. (2010). Corporate leverage, the cost of capital, and the financial crisis in Latin America. Available at SSRN 1577687.

Chahine, S., Filatotchev, I., \& Piesse, J. (2007). The Effects of R\&D Investment and Firm Size on Growth Opportunities of Newly Listed Firms: European Evidence. Available at SSRN 959155.

Davila, A., \& Foster, G. (2005). Startup Firms Growth, Management Control Systems Adoption, and Performance. Working Paper.

Hassani, M., \& Mahdavi Sabet, E. (2013). The examination of signaling theory versus pecking order theory: Evidence from Tehran Stock Exchange. Management Science Letters, 3(1), 119-128.

Houshmand Neghabi, Z., \& Morshedian Rafiee, S. (2013). Investigating different influential factors on capital structure of different sectors of industries listed in Tehran Stock Exchange. Management Science Letters, 3(1), 73-80.

Kjell, B.N., \& Randi, N. (2010). The relationship between bankruptcy risk and growth for non-listed firms. Working Paper.

Kumar, M.A.S., Dhanasekaran, M., Sandhya, S., \& Saravanan, R. (2012). Determination of Financial Capital Structure on the Insurance Sector Firms in India. European Journal of Social Sciences, 29(2), 288-294.

Monica, S., \& Abir, S. (2010). Financial Leverage and Investment Opportunities in India: An Empirical Study. International Research Journal of Finance and Economics, 40, 215-226.

Noravesh, I., \& Yazdani, S. (2010). The survey of the effect of financial leverage on investment in listed companies in the Tehran Stock Exchange. Journal of Financial Accounting Research, 2(2), 35-48.

Piry, P., Imani Barandagh, M., \& Allahverdizadeh, S. (2011). The effect of different periods of the life cycle on profitability and growth of business units. Empirical research of accounting, 1(2), 4966.

Rahnamaye Roodposhti, F., Talebnia, G., \& Soleimanifar, R. (2009). The survey of relationship between cash flows from financing activities and stock returns of listed companies in Tehran stock exchange. Stock securities Journal, 2(8), 65-89.

Sinai, H.A., Solgi, M., \& Mohammadi, K. (2011). The effect of growth opportunities on the relationship between capital structure, dividends and ownership structure with firm value. Journal of Financial Accounting Research, 3(4), 87-102.

Zhao, B., \& Wijewardana, W.P. (2012). Financial Leverage, firm growth and Financial Strength: Evidence in Sri Lanka. Journal of Asia Pacific Business Innovation \& Technology Management, 2, 13-22. 